\title{
Munkarendek a hazai egészségügyi rendszerben, és az ápolók alvásminősége
}

\author{
Fusz Katalin ${ }^{1}$ - Pakai Annamária dr. ${ }^{1}$ - Kívés Zsuzsanna ${ }^{2}$ \\ Szunomár Szilvia ${ }^{1}$ - Regős Annamária ${ }^{3}$ - Oláh András dr. ${ }^{1}$ \\ Pécsi Tudományegyetem, \\ ${ }^{1}$ Egészségtudományi Kar, Ápolástudományi, Alapozó Egészségtudományi és Védőnői Intézet, \\ ${ }^{2}$ Egészségtudományi Kar, Egészségbiztosítási Intézet, \\ ${ }^{3}$ Klinikai Központ, Reumatológiai és Immunológiai Klinika, Pécs
}

\begin{abstract}
Bevezetés: A folyamatos egészségügyi ellátás biztosításának egyik eszköze a műszakbeosztás szerinti munkarend, amely megterhelő és alvászavarhoz is vezethet. Célkitüzés: A hazai fekvőbeteg-szakellátásra jellemző ápolói munkarendek típusainak felmérése, a szabálytalan munkarendek okainak elemzése, továbbá a különböző típusú munkarendek és alvásproblémák összefüggéseinek vizsgálata volt a tanulmány célja. Módszer: Az országos online felmérés során 236 vezető ápoló töltötte ki a saját szerkesztésű kérdőívet, valamint a Pécsi Tudományegyetem klinikáin 217 ápoló a Bergen Váltott Mû́szak Alvás Kérdőívet. Eredmények: Az ápolóvezetők 8697 ápoló munkarendjéről nyilatkoztak, akiknek 51,89\%-a flexibilis váltott múszakos munkarendben dolgozik. Szabályos munkarendben az ápolók 22,35\%-a dolgozik, közülük a legtöbben az alábbi rendben: 12 órás nappali múszak után 12 órás éjszakai múszak, majd 1-2 pihenőnap. Ahol nincs rendszer a múszakok sorában, annak leggyakoribb oka az ápolók igényei és az ápolóhiány. A szabálytalan múszakban dolgozók alvásminősége rosszabb, mint a szabályos és flexibilis munkarendüeké $(\mathrm{p}=0,044)$. Következtetések: Célszerű lenne a legkevésbé megterhelő ápolói munkarendeket kialakítani. Orv. Hetil., 2016, $157(10), 379-384$.
\end{abstract}

Kulcsszavak: váltott műszak, munkarend, álmatlanság

\section{Work schedules in the Hungarian health care system and the sleep quality of nurses}

Introduction: One way of ensuring the continuity of health care is the shift work, which is burdensome and it can lead to sleep disturbances. Aim: The aim of the study was to measure the typical Hungarian nursing shift systems in hospitals, to analyse the causes of irregular work schedules, and to compare the sleep quality of nurses in different work schedules. Method: 236 head nurses filled out the national online survey, and 217 nurses in clinics of the University of Pécs filled the Hungarian version of Bergen Shift Work Sleep Questionnaire. Results: The head nurses provided data of 8697 nurses's schedules. 51.89\% of nurses work in flexible shift system. 1944 employees work in regular shift system, most of them in the following order: 12-hour day shift and 12-hour night shift, followed by a one- or twoday rest. Where there is no system of shifts, the most frequent causes are the needs of nurses and the nurse shortage. Nurses who are working in irregular shift system had worse sleep quality than nurses who are working in flexible and regular shift system $(\mathrm{p}=0.044)$. Conclusions: It would be helpful if the least burdensome shift system could be established.

Keywords: shiftwork, work schedule, sleepiness

Fusz, K., Pakai, A., Kivés, Zs., Szunomár, Sz., Regős, A., Oláh, A. [Work schedules in the Hungarian health care system and the sleep quality of nurses]. Orv. Hetil., 2016, 157(10), 379-384.

(Beérkezett: 2016. január 4.; elfogadva: 2016. január 21.) 
A folyamatos egészségügyi ellátás biztosításának eszköze az ügyelet, a készenlét, valamint a múszakbeosztás szerinti munkarend; ezek szervezeti kérdéseit a 47/2004. (V. 11.) ESzCsM rendelet foglalja össze [1].

Az egészségügyi szolgáltató az ügyeleti ellátást sürgősségi ügyeleti, alapellátás keretében szervezett ügyeleti, eseti ügyeleti, osztályos ügyeleti, valamint összevont osztályos ügyeleti (mátrix) rendszerben, illetve ezek kombinációjával szervezheti meg. Készenléti szolgálat esetén a foglalkoztatott munkára készen rendelkezésre áll a munkavégzés helyszínén kívül, a napi munkaidőn kívül felmerülő feladatok ellátására. Az egészségügyi dolgozó a készenlét teljes tartama alatt munkára képes állapotban áll, és az ügyeletvezető értesítését követően 40 percen belül köteles munkavégzésre megjelenni.

Az alapellátás esetén a háziorvosi és házi gyermekorvosi feladatok rendelési időn kívüli ellátására központi ügyeletet vagy ügyeleti szolgálatot kell szervezni, míg a fogorvosi ellátás folyamatosságát ügyeleti szolgálattal vagy készenléttel biztosítják.

A mentőszolgálatok és a sürgősségi centrumok a folyamatos ellátást megszakítás nélküli, múszak szerinti munkarendben szervezik meg.

A fekvőbeteg-szakellátást nyújtó szolgáltató a fekvőbetegek részére biztosítja a folyamatos egészségügyi szakellátást, emiatt például az orvosok ügyeletet, az ápolók éjszakai múszakot vállalnak. Az orvosok felügyeletének típusai az ügyeleti ellátás keretében a személyes jelenlét mellett végzett felügyelet, telefonos elérhetőség melletti felügyelet, valamint behívásos rendszer keretében megvalósított felügyelet [1]. Az ápolók a több müszakos munkarend keretében végeznek éjszaka munkát, hazánkban általában 12 órás nyújtott múszakban, azaz 18 órától reggel 6 óráig.

A folyamatos ellátás biztosításának eszközei közül jelen kutatásunkban a múszakbeosztás szerinti munkarendet vizsgáltuk meg alaposabban ápolók körében. A múszakbeosztás készítésének nehézségeivel kevés tanulmány foglalkozik. Legrain és mtsai az ápolói müszakbeosztás problémáit elemzik, és javaslatot tesznek két program alkalmazására, amely megkönnyíti a beosztások készítését [2].

A folyamatos egészségügyi ellátás miatt sok egészségügyi dolgozónak éjszaka is dolgozni kell. Számos vizsgálat bizonyította, hogy az éjszakai múszakban végzett munka káros az egészségre, hiszen megzavarja a szervezet biológiai ritmusát $[3,4]$. Az éjszakai múszakban dolgozóknál gyakrabban fordulhat elő metabolikus szindróma, alvászavar, depresszió, daganatos megbetegedés [5-11].

Vizsgálatunk célja, hogy meghatározzuk - az ápolóvezetőktől nyert információk alapján - a leggyakoribb, fekvőbeteg-szakellátásban előforduló több műszakos munkarendeket, valamint a legmegterhelőbb ápolói munkarendet. Feltételezésünk szerint az ápolók nagy része nem szabályos munkarendben dolgozik, amelynek okait vizsgáljuk. Felmérésünkben a szabálytalan munkarendek okaira is rákérdeztünk.

További célunk volt, hogy egy ápolói mintán egzakt módszerekkel igazoljuk a különböző típusú ápolói munkarendek és az alvásproblémák összefüggéseit a Bergen Váltott Mưszzak Alvás Kérdőív alkalmazásával [12, 13].

\section{Módszer}

\section{Minta}

Vizsgálatunk során kvantitatív, leíró jellegű, keresztmetszeti vizsgálatot végeztünk, az ápolásvezetők országos és az ápolók pécsi mintáján. Az adatfelvétel két részből állt, az egyik kérdő́vet az ápolásvezetők, a másikat a fekvőbeteg-szakellátásban dolgozó ápolók részére állítottuk öszsze. Összesen 453 fö vett részt a felmérésben.

Ápolásvezetôi minta: Az Ápolási Igazgatók Egyesületének régióvezetőitől kapott elérhetőségeket kiegészítettük az Állami Egészségügyi Ellátó Központ (ÁEEK) honlapjáról letölthető táblázatban szereplő további intézmények ápolásvezetőinek elérhetőségével [14]. Az ország összes megyéjébe, összesen 173 klinika és kórház ápolási igazgatójának küldtünk elektronikus levelet, amelyben szerepelt az online kérdőív linkje. Kértük, hogy vegyenek részt a vizsgálatban, vagy továbbítsák az osztályvezetó ápolóknak a kérdő́ivet, amennyiben úgy gondolják, az osztályvezetők jobban tudnak válaszolni a múszakbeosztásokkal kapcsolatos kérdésekre. A visszaérkezett 242 kérdőívből 236 volt értékelhető: 28 intézetés 208 osztályvezető ápolóé.

Ápolói minta: A mintavétel módja egyszerü, nem véletlenszerü mintavétel történt a következő intézményekben: Pécsi Tudományegyetem, Klinikai Központ, Szívgyógyászati Klinika, Szülészeti és Nőgyógyászati Klinika, Neurológiai Klinika, Pszichiátriai és Pszichoterápiás Klinika, Reumatológiai és Immunológiai Klinika, valamint a Gyermekgyógyászati Klinika. A kiosztott 388 darab kérdőívből 217 (65,9\%) volt értékelhető.

\section{Méröeszközök}

Ápolásvezetők kérdőive: A saját szerkesztésű anonim kérdőív összesen 14 kérdést tartalmaz. A kitöltőről csupán két információ derül ki: melyik megyében dolgozik és intézet- vagy osztályvezető ápoló-e. A további kérdések az ápolói létszámokkal és múszakrendekkel kapcsolatosak.

Az ápolók számára készült kérdőív a szociodemográfiai jellemzők mellett a Standard Shiftwork Indexben [15] szereplő kérdések segítségével a dolgozók munkarendjének szabályosságát méri fel (szabályos, flexibilis és szabálytalan).

A Bergen Shift Work Sleep Questionnaire [11] magyar nyelvre adaptált változata, a Bergen Váltott Múszak Alvás Kérdőív (BSWSQ-H) [12] az alvásminőséget és annak ébrenlétre gyakorolt hatásait vizsgálja több mü- 
szakos munkarendben dolgozóknál a különböző múszakokban és szabadság esetén. A kérdőív ötfokozatú Likert-skálákat alkalmaz, amelyek az egyes panaszok gyakoriságát mérik, és a magasabb pontértékek rosszabb alvásminőséget jeleznek.

\section{Statisztikai elemzés}

A statisztikai elemzéseket az SPSS 20.0 programcsomaggal végeztük (SPSS, Chicago, IL).

A leíró statisztikai elemzés (abszolút és relatív gyakoriság, átlag, szórás) mellett egy szempontos varianciaanalízist és Scheffe post hoc tesztet használtunk. Az eredményeket mindegyik teszt esetén $\mathrm{p}<0,05$-nél tekintettük szignifikánsnak.

\section{Eredmények}

\section{A vezetó ápolók körében végzett felmérés}

Országos felmérést végeztünk annak kiderítésére, hogy az egyes intézményekben milyen müszakrendekben dolgoznak az ápolók. Az osztály- és intézetvezetóápolók összesen 8697 ápoló munkarendjéről nyilatkoztak.

Az ápolók 51,89\%-a $(\mathrm{n}=4513)$ flexibilis váltott múszakos munkarendben dolgozik, vagyis esetükben az igényeikhez igazodva készül a beosztás, nem szabályos munkarendben.

Szabályos váltott múszakos munkarendben összesen 1944 ápoló $(22,35 \%)$ dolgozik, közülük a legtöbben, 1385-en az alábbi rend szerint: egy 12 órás nappali müszakot követóen egy 12 órás éjszakai múszak, majd egy vagy kettő pihenőnap következik (1N-1É-1/2P). Gyakori még, hogy két 12 órás nappali múszakot követ egy éjszakai múszak (2N-lÉ-2/3P), de ez a múszakrendtípus több vezető szerint nagyon megterhelő. Nyolcórás szabályos váltott múszakos munkarendben ( 5 nappali müszak, 2 pihenőnap, 5 délutáni múszak, 2 pihenőnap, majd 5 éjszakai múszak: $5 \mathrm{~N}$ [8 órás]-2P-5D-2P-5E) csak 9 fó $(0,10 \%)$ dolgozik. 666 fö $(7,66 \%)$ esetén a vezetők szerint nem lehet igazodni a dolgozó igényeihez, és szabálytalan munkarendet állítanak össze.

Csak nappal, azaz nappali munkarendben 1541 fó $(17,72 \%)$, míg csak éjszakai vagy fooként éjszakai műszakban $33(0,38 \%)$ ápoló dolgozik (1. táblázat).

A mû́szakbeosztást készítő vezetőket megkérdeztük, hogy amennyiben nincs rendszer a műszakok esetén, mik ennek az okai. A válaszadó vezető ápolók 62,43\%-a (118 fö) szerint egyrészt az ápolók egyéni igényei (például családi okok, vidékről bejárás, tanulmányok), másrészt az ápolóhiány $(32,3 \%)$. További okokként említették a szabadságolásokat és a mellékállást vállalók nagy számát (2. táblázat).

Felmértük, hogy a vezető beosztású ápolók tapasztalata szerint melyik a megterhelőbb: a rövidebb ciklusú, azaz ha egy-két éjszakai múszak követi egymást, majd egy-két pihenőnap és nappali müszak, aztán ismét egykét éjszaka; vagy a hosszabb ciklusú, azaz ha egymás
1. táblázat Ápolói munkarendek Magyarországon - a vizsgálatban részt vevő intézmények ápolásvezetőinek $(\mathrm{n}=236)$ beszámolója alap-

\begin{tabular}{|c|c|c|}
\hline Típus & $\mathrm{n}$ & $\%$ \\
\hline Nappali munkarend & 1541 & 17,72 \\
\hline Csak éjszakai/főként éjszakai múszak & 33 & 0,38 \\
\hline Szabálytalan & 666 & 7,66 \\
\hline Flexibilis & 4513 & 51,89 \\
\hline $\begin{array}{l}1 \mathrm{~N}-1 \mathrm{E}-1 / 2 \mathrm{P} \\
1 \text { nappali müszak-1 éjszakai müszak-1/2 pibenónap }\end{array}$ & 1385 & 15,92 \\
\hline $\begin{array}{l}2 \mathrm{~N}-1 \mathrm{E}-2 / 3 \mathrm{P} \\
2 \text { nappali müszak-1 éjszakai müszak-2/3 pibenönap }\end{array}$ & 451 & 5,19 \\
\hline $\begin{array}{l}2 \mathrm{~N}-2 \mathrm{P}-2 \mathrm{E}-2 \mathrm{P} \\
2 \text { nappali müszak-2 pibenönap-2 éjszakai müszak- } \\
2 \text { pihenönap }\end{array}$ & 75 & 0,86 \\
\hline $\begin{array}{l}\text { 1N-2É-2/3P } \\
\text { I nappali müszak-2 éjszakai müszak-2/3 pihenönap }\end{array}$ & 20 & 0,23 \\
\hline $\begin{array}{l}2 \mathrm{~N}-2 \mathrm{E}-3 / 4 \mathrm{P} \\
2 \text { nappali müszak-2 éjszakai müszak-3/4 pihenönap }\end{array}$ & 4 & 0,05 \\
\hline $\begin{array}{l}5 \mathrm{~N} \text { (8 órás })-2 \mathrm{P}-5 \mathrm{D}-2 \mathrm{P}-5 \mathrm{E} \\
5 \text { nappali múszak-2 pibenönap-5 délutáni- } \\
2 \text { pibenőnap-5 éjszakai müszak-2 pibenönap }\end{array}$ & 9 & 0,10 \\
\hline Összesen & 8697 & 100,0 \\
\hline
\end{tabular}

2. táblázat |A szabálytalan, flexibilis munkarendek okai vezető ápolók szerint $(\mathrm{n}=189)$

\begin{tabular}{lcc}
\hline & $\mathrm{n}$ & $\%$ \\
\hline Ápolók igényei (például családi okok, iskola) & 118 & 62,43 \\
Ápolóhiány & 61 & 32,28 \\
Szabadságok kiadása & 20 & 10,58 \\
Mellékállást vállaló kollégák & 19 & 10,05
\end{tabular}

után több éjszakai műszak követi egymást. A válaszadók $45,5 \%$-a szerint a hosszabb ciklusú, $39,4 \%$-uk szerint a rövid ciklusú munkarend a megterhelőbb, míg 14,8\% nem tudta eldönteni, melyik a rosszabb.

Egyesek szerint az egymás után következő két 12 órás nappali múszak nagyon fárasztó, mások szerint az a megterhelő, ha egyik nap nappalos, másik nap éjszakás a dolgozó.

\section{A Pécsi Tudományegyetem klinikáin dolgozó ápolók körében végzett felmérés}

A Pécsi Tudományegyetem, Klinikai Központ hat klinikáján összesen 217 ápoló vett részt a kérdőíves felmérésben. A kérdőívet kitöltők 88,9\%-a nő, valamint átlagéletkoruk 38,53 év (SD 10,02, minimum: 21, maximum: 60). A résztvevők 60\%-a házastársi/élettársi kapcsolatban él, valamint 40,6\%-a gyermeket nevel, továbbá leggyakoribb iskolai végzettség az E kategóriás ápoló ( $\mathrm{n}=$ $137,63,1 \%)$. 
A válaszadó ápolók átlagosan 16,42 éve (SD: 11,32, minimum: 1, maximum: 40) dolgoznak az egészségügyben, és a jelenlegi múszakrendben 8,83 éve $(S D: 8,24)$. Mellékállása 36 fónek $(16,6 \%)$ van, havonta 6 éjszakai múszakot vállalnak átlagosan, és a válaszadók 49,5\%-a nem részesíti előnyben az éjszakai munkát. Az éjjeli munkavégzés során a megvilágítás a válaszadók $82 \%$-a szerint megfelelő (nem túl gyenge, és nem is túl erős).

Felmértük a kávé- és energiaital-fogyasztásukat is, amely szerint a legtöbben $(\mathrm{n}=122,56,5 \%)$ naponta $1-2$ csésze kávét fogyasztanak, és nem isznak energiaitalt ( $\mathrm{n}=$ $148,68,2 \%)$. Az alvásminőséggel összefüggésbe hozható altatót a minta $5,7 \%$-a szed.

A legtöbben $(\mathrm{n}=96,44,24 \%)$ flexibilis váltott múszakos munkarendben dolgoznak, azaz a múszakbeosztáskor igazodik az osztályvezető ápoló az igényeikhez. Szabályos több múszakos munkarendben mindössze 30 fó $(13,82 \%)$ dolgozik. A legtöbben közülük $(\mathrm{n}=24)$ egy 12 órás nappali múszakot követően egy 12 órás éjszakai múszakot vállalnak, majd egy vagy kettő pihenőnap következik (1N-1É-1/2P).

$\mathrm{Az}$ ápolók 50\%-a gondolja úgy, hogy a hosszú ciklusú munkarend a megterhelóbb, és ugyanannyian azt, hogy a rövid ciklusú a rosszabb.

Elemeztük az alvásminőség és a különböző ápolói munkarendek kapcsolatát, ehhez a BSWSQ-H kérdő́ivet választottuk, amely a több múszakos munkarendben dolgozók diszkrét alvászavarainak és nappali fáradtságának vizsgálatára szolgál. Mivel a kérdőív a váltott múszakban dolgozókra vonatkozik, emiatt a nappali munkarendben $(\mathrm{n}=53)$ és a csak/főként éjszakai múszakban $(\mathrm{n}=2)$ dolgozókat kihagytuk az elemzésből. Az ápolók $56,79 \%$-a egyes múszakoknál a „nem dolgozott ilyen múszakban" választ jelölte, tehát csak 92 fó pontjaival tudtuk kiszámolni a BSWSQ-H összes kérdésre vonatkozó átlagát, amely 36,83 pont lett (SD: 18,11 pont).

A nem $(\mathrm{p}=0,255)$, a kor $(\mathrm{p}=0,599)$, az együttélés típusa $(\mathrm{p}=0,876)$ és az iskolai végzettség $(\mathrm{p}=0,760)$ alapján a BSWSQ-H-értékben nem volt szignifikáns különbség.

A munka helyszíne alapján a Reumatológiai és Immunológiai Klinika dolgozói jelezték ( $\mathrm{n}=20$, BSWSQ-Hnappali: 12,70 pont) a legrosszabb alvásminőséget a nappali múszak utáni alvás esetén $(\mathrm{F}=3,099, \mathrm{p}=0,011)$, a legalacsonyabb pontot pedig a Szülészeti és Nőgyógyászati Klinika ápolói kapták ( $\mathrm{n}=42$, BSWSQ-H-nappali: 8,45 pont).

Nappali $(\mathrm{F}=3,24, \mathrm{p}=0,042)$ és délutáni munkavégzés $(\mathrm{F}=4,37, \mathrm{p}=0,016)$ esetén a legrosszabb alvásminőséget a szabálytalan munkarendben dolgozók esetén mértük, továbbá a BSWSQ-H összesített pontjai alapján is a szabálytalan munkarendúek kaptak legmagasabb pontot $(\mathrm{F}=3,24, \mathrm{p}=0,044)(\mathrm{l}$. ábra). A post hoc teszt alapján a szabálytalan munkarendúek alvásminősége csak a flexibilis munkarendúekétől különbözik az összesített pontok esetén $(\mathrm{p}=0,013)$.

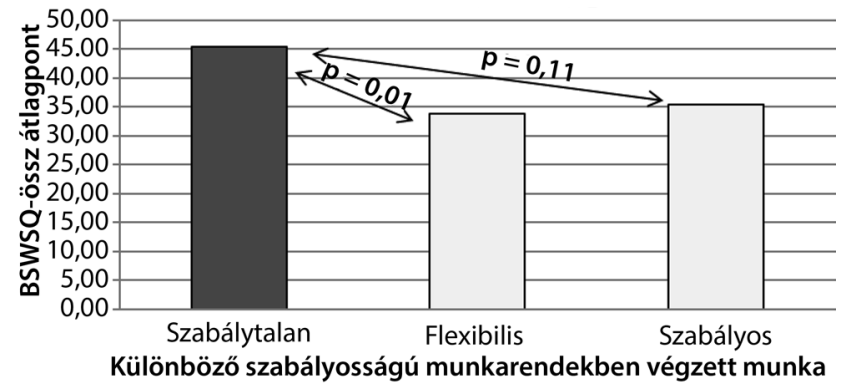

1. ábra Alvásminőség a különböző múszakrendek (szabálytalan, flexibilis, szabályos) esetén $(\mathrm{n}=162, \mathrm{p}=0,044)$

Az alvásminőséget nem befolyásolta, hogy van-e mellékállása, hogy mióta dolgozik az egészségügyben $(\mathrm{p}=$ $0,405)$ és a jelenlegi munkarendben $(\mathrm{p}=0,450)$, valamint a havi éjszakai múszakok száma $(\mathrm{p}=0,114)$, továbbá az éjszakai megvilágítás sem $(\mathrm{p}=0,252)$. A kis elemszámú csoportok miatt eltekintettünk a szabályos váltott múszakos munkarendek típusainak összehasonlításától.

Akik nem részesítik előnyben az éjszakai munkavégzést, jobb alvásminőségról számoltak be nappali múszak $(\mathrm{t}=2,11, \mathrm{p}=0,037)$ és pihenónap esetében $(\mathrm{t}=2,66, \mathrm{p}$ $=0,009)$.

Az alvásminőséggel kapcsolatosan felmértük a válaszadók kávé- és energiaital-fogyasztását, továbbá, hogy szednek-e alvásproblémára gyógyszert. A kávéfogyasztás esetén szignifikáns különbséget kaptunk a pihenőnap/ szabadság esetén tapasztalt alvásproblémák és nappali fáradtság terén, ugyanis a 3 (vagy több) csésze kávét fogyasztók érték el a legmagasabb pontot a BSWSQ-H skálán $(\mathrm{n}=42$, BSWSQ-H-pihenőnap: 7,95 átlagpont, SD: 4,$488 ; \mathrm{p}=0,047)$.

\section{A vezetó ápolók és a Pécsi Tudományegyetem ápolóinak összehasonlitása}

A két csoportban kapott eredményeket összehasonlítottuk a múszaktípusok megoszlása alapján. Az országos mintában és a PTE klinikáin dolgozó ápolók esetén is a leggyakoribb munkarend a flexibilis (51,89\% és $44,24 \%)$. A szabályos váltott múszakos munkarendek közül a legnépszerúbb a 12 órás nappali múszakot követő 12 órás éjszakai múszak, majd egy/kettő pihenőnap ( $1 \mathrm{~N}-1 \mathrm{E}-$ $1 / 2 \mathrm{P})$.

Mindkét kérdő́ívben szerepelt az a kérdés, hogy melyik munkarendet tartják megterhelőbbnek, a rövid vagy a hosszú ciklusút. A vezető ápolók 46,6\%-a $(\mathrm{n}=135)$ a hosszú ciklusú munkarendet tartja megterhelóbbnek, és kevesebben $(41,4 \%, n=120)$ gondolják úgy, hogy a rövid a megterhelőbb, 35 fó pedig „nem tudom” választ jelölt. A PTE klinikáin dolgozó ápolók esetén $50 \%$ szerint a hosszú, $\mathbf{5 0} \%$ szerint a rövid ciklusú munkarendben nehezebb dolgozni.

Mindkét csoportban felmértük, hogy az ápolók előnyben részesítik-e az éjszakai munkát. A PTE klinikáin dolgozó ápolók 49,5\%-a egyáltalán nem részesíti előnyben 
az éjszakai munkát, míg a vezető ápolók szerint csupán az ápolók 19,1\%-a nem dolgozik szívesen éjszakai müszakban. Az intézet-, illetve az osztályvezető ápolók szerint az ápolók 61,4\%-a a több fizetés miatt választja az éjszakai munkát, míg az ápolók csupán 29,2\%-a vállalja az éjszakai múszakot a több fizetés miatt.

\section{Megbeszélés}

Országos vizsgálatunk során a vezető ápolók 8697 ápoló munkarendjéről nyilatkoztak. Az ápolók 51,89\%-a flexibilis (azaz rugalmasan szabálytalan) váltott múszakos munkarendben, míg 7,66\% szabálytalan munkarendben dolgozik. Szabályos váltott múszakos munkarendben mindössze az ápolók 22,35\%-a dolgozik összesen. Igazolódott tehát a hipotézisünk, miszerint Magyarországon kevés ápoló dolgozik szabályos több mûszakos munkarendben.

A leggyakoribb szabályos váltott múszakos munkarend: egy 12 órás nappali múszakot követően egy 12 órás éjszakai múszak, majd egy vagy kettő pihenőnap következik (1N-1É-1/2P). Griffiths és mtsai a 12 európai országban végzett kutatásukban a múszakok hosszát és azok hatásait elemezték ápolók körében. A megkérdezett 31627 ápoló $50 \%$-a $\leq 8$ órás múszakokban dolgozik, csupán $15 \%$ dolgozik a hazánkban népszerü $\geq 12$ órás múszakban. Eredményeik szerint a 12 órás vagy annál hosszabb múszak esetén csökken a betegbiztonság és az ellátás minősége [16].

Ott, ahol nincsen rendszer a múszakok esetén, a vezetô ápolók leggyakoribb okoknak az ápolók igényeit, az ápolóhiányt, a szabadságok kiadását, valamint a mellékállások vállalását írták le. Tehát a legtöbb helyen azért van flexibilis müszakbeosztás, mert a vezetó ápolók megpróbálnak alkalmazkodni az ápolók igényeihez. Továbbá az ápolóhiány is nagy szerepet játszik abban, hogy nem tudnak szabályos rendszerú múszakbeosztást készíteni. Magyarországon jelentős probléma az ápolók elvándorlása, a humán erőforrás hiánya; Betlehem vizsgálata szerint az ápolói munkakörök száma 2006 és 2010 között 8\%-kal csökkent [17].

Eredményeink szerint a szabálytalan váltott múszakban dolgozó ápolók alvásminősége rosszabb, mint a szabályos és flexibilis munkarendben dolgozóké $(\mathrm{p}=0,044)$. Korábbi vizsgálatunkban is ezt az eredményt kaptuk, vagyis a múszakrendek szabálytalansága megterhelő a dolgozók számára [13]. A megkérdezett ápolók ugyanolyan arányban érzik megterhelőnek a hosszabb és a rövidebb ciklusú munkarendeket is. Akik nem részesítik előnyben az éjszakai múszakot, jobb alvásminőségről számoltak be nappali múszak $(\mathrm{p}=0,037)$ és szabadnap ( $\mathrm{p}=0,009)$ esetén.

Eredményeinket korlátozta, hogy a minta nem reprezentatív, és a PTE klinikáin végzett felmérés kis elemszámú. Munkánk folytatásaként a különböző szabályos munkarendek összehasonlítását tervezzük az egészségre kifejtett hatásuk alapján.
Anyagi támogatás: A közlemény megírása, illetve a kapcsolódó kutatómunka anyagi támogatásban nem részesült.

Szerzői munkamegosztás: F. K.: A hipotézisek kidolgozása, a kérdőív összeállítása, a vizsgálat lefolytatása, statisztikai elemzés, a kézirat megszövegezése. P. A., O. A.: A hipotézisek kidolgozása, a kézirat megszövegezése. K. Zs.: A kérdőív összeállítása, a kézirat megszövegezése. Sz. Sz.: Szakirodalmi áttekintés, adatbázis készítése. R. A.: A kérdőív kiosztása, adatbázis készítése. A cikk végleges változatát valamennyi szerző elolvasta és jóváhagyta.

Érdekeltségek: A szerzőknek nincsenek érdekeltségeik.

\section{Köszönetnyilvánítás}

A jelen tudományos közleményt a szerzők a Pécsi Tudományegyetem alapításának 650. évfordulója emlékének szentelik. Köszönetünket fejezzük ki minden ápolónak, aki kitöltötte a kérdőívet.

\section{Irodalom}

[1] Decree No. 47/2004 (V. 11) of the Ministry of Health, Social and Family Affairs on some organizational question of continuous operation of health care. [47/2004. (V. 11.) ESzCsM rendelet az egészségügyi ellátás folyamatos múködtetésének egyes szervezési kérdéseiről.] http://net.jogtar.hu/jr/gen/hjegy_ doc.cgi?docid=A0400047.ESC [Hungarian]

[2] Legrain, A., Bonarab, H., Labrichi, N.: The nurse scheduling problem in real-life. J. Med. Syst., 2015, 39(1), 160.

[3] Weibel, G., Brandenberger, G.: Disturbances in hormonal profiles of night workers during their usual sleep and work times. J. Biol. Rhythms, 1998, 13(3), 202-208.

[4] Sanders, D. C., Chaturvedi, A. K., Hordinsky, J. R.: Melatonin: aeromedical, toxicopharmacological, and analytical aspects. J. Anal. Toxicol., 1999, 23(3), 159-167.

[5] van Mark, A., Spallek, M., Kessel, R., et al.: Shift work and pathological conditions. J. Occup. Med. Toxicol., 2006, 1, 25.

[6] Halmos, T., Suba, I.: The role and significance of diurnal rhythm in the clinical. [A napi ritmus szerepe és jelentősége a klinikumban.] Magyar Tudomány, 2013, 174(1), 96-102. [Hungarian]

[7] Lee, C. Y., Chen, H. C., Meg Tseng, M. C., et al.: The relationships among sleep quality and chronotype, emotional disturbance, and insomnia vulnerability in shift nurses. J. Nurs. Res., 2015, 23(3), 225-235

[8] Flo, E., Pallesen, S., Magerøy, N., et al.: Shift work disorder in nurses - assessment, prevalence and related health problems. PLoS ONE, 2012, 7(4), e33981.

[9] Fusz, K., Kovács, K., Kivés, Zs., et al.: Effects of nursing shift schedules using Standard Shift Work Index - pilot study. [Ápolói müszakrendek hatásainak vizsgálata Standard Shiftwork Index alkalmazásával - pilot vizsgálat.] Nővér, 2014, 27(4), 3-10. [Hungarian]

[10] Esquirol, Y., Perret, B., Ruidavet, J. B., et al.: Shift work and cardiovascular risk factors. New knowledge from the past decade. Arch. Cardiovasc. Dis., 2011, 104(12), 636-668.

[11] Hansen, J., Stevens, R. G.: Case-control study of shift-work and breast cancer risk in Danish nurses. Impact of shift systems. Eur. J. Cancer, 2012, 48(11), 1722-1729.

[12] Flo, E., Bjorvatn, B., Folkard, S., et al.: A reliability and validity study of the Bergen Shift Work Sleep Questionnaire in nurses working three-shift rotations. Chronobiol. Int., 2012, 29(7), 937-946. 
[13] Fusz, K., Tóth, Á., Fullér, N., et al.: Sleep quality of nurses working in shifts - Hungarian adaptation of the Bergen Shift Work Sleep Questionnaire. [Váltott múszakban dolgozó ápolók alvásminőségének vizsgálata a magyar nyelvre adaptált Bergen Shift Work Sleep Questionnaire alkalmazásával.] Orv. Hetil., 2015, 156(49), 2003-2008. [Hungarian]

[14] Healthcare providers maintained by the National Healthcare Service Center in Hungary. [Az Állami Egészségügyi Ellátó Központ fenntartásába tartozó egészségügyi szolgáltatók.] http:// www.gyemszi.hu/aeek/home/kozerdeku_adatok/aeek/kozerdeku_adatok/szervezeti_adatok/upload/kozfeladatot_ellato_ es_gazdalkodo_szervezetek_kozalapitvanyok [Hungarian]

[15] Barton, J., Costa, G., Smith, L., et al.: The Standard Shiftwork Index: A battery of questionnaires for assessing shiftwork-related problems. Work Stress, 1995, 9, 3-30.
[16] Griffiths, P., Dall'Ora, C., Simon, M., et al.: Nurses' shift length and overtime working in 12 European countries - the association with perceived quality of care and patient safety. Med. Care, 2014, 52(11), 975-981.

[17] Betlehem, J.: Main characteristics of the human resources situation of health care workers in 2012. [Az egészségügyi szakdolgozók humánerőforrás helyzetének főbb jellemzői 2012-ben.] Népegészségügy, 2012, 90(2), 77-83. [Hungarian]

(Oláh András dr., Pécs, Vörösmarty u. 4., 7621 e-mail: andras.olah@etk.pte.hu)

\section{Eladó praxis}

Budapesten a XX. kerületben házi gyermekorvosi körzet praxisjoga eladó!

Lakosság száma 784 fő, a kártyaszám 670 db. A praxis megvásárlásához az OEP-hez vissza nem térítendő támogatás iránt pályázat nyújtható be. A körzet a lakosság száma tekintetében megfelel a pályázati feltételeknek. Az ár alkuképes.

Érdeklődni: Dr. Mozi Diana, Tel: 30/ 999-59-72 